\title{
SCIENTIFIC LEADERS FOR THE FUTURE: PRIMARY AND SECONDARY EDUCATION
}

\author{
Preparando lideranças científicas para o futuro: ensino médio e fundamental
}

Fernanda Amorim de Morais Nascimento', Bianca Martins Gregório², Diogo Benchimol de Souza², Francisco José Barcellos SAMPAIO ${ }^{3}$, Lydia MaSAKo FerReIRA ${ }^{4}$

\section{A B STR A C T}

Objective: To present a high school insertion pilot project in post graduate programs (PPG) and discuss the mechanisms for the formation of leaders in science. Methods: This study presents a review and pilot project. Bibliographic search occurred in sites of CAPES, MEC, SciELO and library of virtual books from January/ 2014 to February/2015. The pilot is in PPG-Medicine III Translational Surgery/UNIFESP and Pathophysiology and Surgical Sciences / UERJ. The junior undergraduate students (ICj) came from public school and develop scientific activities: scientific meetings, graduation and inclusion in research projects. The evaluation will occur at the end of one year, with the results essays, reports and participation in scientific events. Results: In Brazil, one of the main challenges of education is the high average years of study. The PNPG (2011-2020) shows the insertion of basic education in all PPG. In the Pathophysiology and Surgical Sciences/UERJ there are currently 11 high school students who have followed the scientific meetings and are being prepared for the inclusion in research projects. There was 30\% of absence, owing to the high school hours. This result and the experience allow creating future alternatives to enhance the integration project. Conclusion: The leadership in science is formed from a complex relationship between basic education and investment in research. PPG-Medicine III courses follow the vanguard with initiatives focused on scientific and technological development. Thus, projects involving basic education students represent promoter model and environment leaders.

Key Words: Post graduation. Education. Secondary school. Basic education. Leadership.

\section{INTRODUCTION}

$T_{\text {we }}^{\text {he }}$ he problems faced by Brazilian education have been widely discussed in various media, scientific or not. Thus, the daily challenges, the existing educational problems and future prospects are topics of interest, especially when related to political and educational background of a society. Still it is important to add that, direct or indirectly, education impacts in the growth process, on income generation ${ }^{1}$, on human capital creation, in is universality and, also, forms social and economic organization².

Scientific research is a reflection of these educational parameters. However, despite the public policies to encourage and support scientific and technological development, since the 1960s, the Brazilian scientific production still reflects significant weaknesses, especially when compared to the production of other countries. Much of this weakness is due not only to the financial dependence on the government, unlike other international research centers in which private capital investment is significant, but also the weaknesses of education and training human formation ${ }^{3}$.

The situation of many young Brazilian children is considered critical, as there are significant deficiencies in the school curriculum and in the training process. Furthermore, in Brazil, in many educational centers (primary and secondary education) there are relevant indexes of scholar evasion, often related to the old based curricular aspects and the combination of multiple activities. For many young people and children, to enter the labor market begins before age ten ${ }^{4}$. Therefore, the transition and evolution of society go through economic, social, technological restructuring and, of course, education. This entire process requires specialized services, with consequent formation of human material of high rate of knowledge ${ }^{2}$.

Thus, there is much discussion about the close relationship between education and scientific development, which also aligns itself with the formation of leaders. In this context, experts say that investment in educational training, should be in the middle or elementary school, and it seems to be the central focus of nation development.

Therefore, this article was elaborated to promote and discuss the importance of science inclusion on young people of primary and secondary education, and also discuss the mechanisms of leaders in science formation, in order to seek consequent social, technological and economic development.

\section{METHODS}

This is a review study and presentation of a pilot project conducted in January 2014 to February 2015 period. The electronic databases search used the sites of CAPES (Higher Education Personnel Training Coordination), MEC (Ministry of Education ), SCIELO (Scientific Electronic Library Online) and the library of virtual books. The keywords used were: graduate, education, high school, elementary school and leadership. The pilot project of integration of high school students from public school, was held in the format of partnership between the postgraduate programs of Medicine III: Translational - UNIFESP and Pathophysiology and Surgical Sciences - UERJ.

In the pilot project mentioned above, post-doctors and teachers became guardians of high school students in the various actions undertaken. In general, the main objective was to stimulate and creates the interest of students to research and science. The first practical actions occurred in the second half of 2014 and are being analyzed. The hypothesis is that the preliminary results of this project would be able to enhance integration program, with the inclusion of elementary school students.

For implementation of the pilot project, the first step was to choose participating schools, which should be public and near to research units. The chosen schools should write their participation by signing a consent term. Then a lecture at the school was made, whose theme was the landscape of science in Brazil and the importance of the school curriculum in scientific and technological development. After the presentation, young volunteers were request to visit the research units. However, the stage was started only after consent terms by

${ }^{1}$ Postgraduate Program in Pathophysiology and Surgical Sciences at the State University of Rio de Janeiro, Rio de Janeiro, RJ;

2Postgraduate Program in Translational Surgery, Federal University of São Paulo, São Paulo, SP, and CAPES Medicine III Area Coordination, Brasília, DF, Brazil.

${ }^{3}$ Professor and Graduate Coordinator General Pathophysiology and Surgical Sciences, Urogenital Research Unit, and Professor in the Department of Human Anatomy of the State University of Rio de Janeiro, Rio de Janeiro, RJ; CNPq Researcher $1 \mathrm{~A}$

${ }^{4}$ Professor in the Graduate Program in Translational Surgery and Professor of the Department of Plastic Surgery at the Federal University of São Paulo, São Paulo, SP, Brazil, Coordinator Area Medicine III of CAPES, CNPq Researcher 1 A. 
the legal guardian were signed.

The pilot program was initiate after leveling classes in science and biology, theoretical and practical research and the application of general knowledge quizzes, held in three stages: 1) pre-insertion and before leveling classes; 2) after leveling classes; 3 ) post-insertion in theoretical and practical research. The research classes aimed to motivate and generate knowledge of the main techniques and methods used in these main programs, such as: human anatomy, bio-security, ethics in basic research and statistics. It is expected that at the end of the theoretical and practical part, students entered as "Junior scientific research" more consolidated in scientific basis for various applications and better monitoring projects in which they participate, which will be evaluated by a test. Compliance with the workload was established with flexibly, respecting school workload and the availability of students, with an average of six hours per week.

Finally, at the end of a year of probation, the participation of these students will be evaluated, aiming presentations, participation in congresses, symposia and events in the area.

\section{RESULTS}

In the electronic databases literature review the following issues are correlated with the context of this article and are described bellow.

The influence of the history of Brazilian education in the current scientific and technological training

Scientific and technological development is related to social and educational issues. This relationship impacts on income generation, knowledge production and is able to reduce inequalities, whether social or scientific. Thus, in countries where there are educational investment and inclusion of young people in the academic and technological means, substantially, there is development of patents, scientific production and international recognition ${ }^{5}$. In Brazil, despite the increasing investment in science and the significant increase in scientific production in recent decades, there is still a gap when it is compared to other countries ${ }^{6}$. These issues are intertwined with the history of Brazilian education, item we want discuss better in this topic.

The complete understanding of the aforementioned facts is done in the range of issues related to education: past and preparation for the future. In fact, any time is marked by its own social moment, imprinting its mark on educational methods and curricula. In the process of colonization, Brazil prioritized human development aimed to work, as the main activities were related to agriculture, or the liberal arts education (letters, philosophy, arts and theology), all these offered only to men. The technological and scientific knowledge was possible only to the children of economically previledged families in the main universities of Europe. This organizational pattern of education is extended for more than 200 years, when in 1759 the Jesuits were expelled. This act was influenced by the illuminism and revolutionary ideas for newly arrived young people from European universities ${ }^{7}$

The first educational reform only occurred with the implementation of public education, designed by the Marquis of Pombal, who installed a system of royal schools, which included classes in the humanities, but without little change from what was by the Jesuits. With this, Brazil further distanced himself from the major scientific achievements of Europe ${ }^{8}$. In 1808 , with the arrival of the Portuguese royal family, there was industrial change and the beginning of university activities ${ }^{7}$. However, education still did not meet the real needs of the Brazilian people, it being elitist mostly and, therefore, against the international developments.

The second major education reform happened for the actions of Francisco Campos, from 1931 when the Ministry of Education and Health, shared the teaching in two cycles: fundamental (five years) and complementary (two years). In addition, Francisco Campos also created the National Education Council (CNE) and defined the model of a university to be adopted in Brazil ${ }^{7}$. However, in this context, research and postgraduate studies were included in the Brazilian in academia, but independent of private capital, which not only differed from other countries in the same period, but contributed to the Brazilian international technological dependence. In foreign universities, research had been introduced in the nineteenth century, and already in the 1930s, had private investment for postgraduate scholarships, as is the case at the Massachusetts Institute of Technology (Massachusetts Institute of Technology - MIT). Thus, is understandable the significant industrial and technological production, high mobilization of innovation and high development of postgraduate, in countries like the United States, since the educational attainment were not new and there was emphasis on collaboration between academia and the industrial sector ${ }^{9}$.

For Brazil, it is important reflections and actions aimed at restoring the lost advances. Once understood the Brazilian educational historical context is plausible to understand the failures we suffered, in innovation for example, although increasing every decade ${ }^{10}$. We must raise the quality of human formation, so that significant improvements in science, with consequent social transformations, may occur. Brazil already has the examples of this direct relationship, but it is important more shares to the formation of new leaders in science, since they can symbolize future growth and development for society.

\section{The training of scientific leaders}

The consensus for many theorists is to relate leadership with the ability to communicate and organize simple/complex thoughts, so that specific goals can be reached ${ }^{11}$. In general, requires the transformation of knowledge into critical awareness. Thus, in order to have training people able to act as leaders in science, one should stimulate their critical sense. Often the leader will be the one who will seek information and identify problems in order to generate changes and take decisions ${ }^{12}$

Back to the correlation between the formation of leaders and the technological advances of a nation, Technological Development and Innovation Chapter of the National Plan of Graduate Studies for 2011-2020 (PNPG 2011-2020), published in 2010, brought some important Brazilian examples about solving problems and creating technology. This process, in turn, is supported by the entrepreneurial university and the formation of differentiated human capital ${ }^{5}$. Therefore, it is consistent to think school as a promoter of environmental leaders.

It should be added that the PNPG 2011-2020 presents a strategic issue, the inclusion of basic education (primary and secondary education) in all postgraduate courses. In the area of Medicine III, scientific projects are offered to students of basic public education and will be discussed later. Are highlighted below the main models of international and national experiences for the promotion and training of leaders in science. Brazil

Challenges in the formation of scientific leaders in

The Brazilian scientific production is increasing. Every new assessment visualize increase in publications in international journals, as well as the increase in indexing of journals in bibliographic databases. Another important factor is the formation of masters and doctors. The PNPG 2011-2020 estimates that there are average training 10.0000 young doctors a year in Brazil. However, there is decreasing relationship between the number of trained doctors and the number of publications and patents, registering numbers less than 4,000 per year ${ }^{9}$.

Given the above, we can see important gap, because despite the significant growth, the Brazilian postgraduate have 
to live with low levels of basic education, as shown by the latest reports from the Ministry of Education (MEC) of 2013. For the MEC one of the main challenges of basic education is the high average years of schooling that shows up in different regions. In general there are a number of young people lag in relation to age, grade and corresponding educational step. These are also referred to by educators as one of the reasons for truancy. It should be added that sum up the challenges described above, the need to implement improvements in the training process and access to information, technology and innovative proposals ${ }^{13}$.

\section{Pilot project}

The results obtained from the pilot project developed at PPG in Pathophysiology and Surgical Sciences (Urogenital Research Unit) - UERJ, in partnership with PPG Tranlacional UNIFESP, had the following findings.

\section{Partial results}

Currently, the pilot project has the participation of 11 high school students from UERJ Application School (CAPUERJ). All develop voluntary stage and attended the lectures on Science Panorama in Brazil and the School Curriculum: Importance of Scientific and Technological Development. Among the actions taken so far included: 1) basic knowledge of questionnaire about science and biology; 2) participation of the scientific meetings of the PPG; 3) class of leveling; 4) participation as listeners in theoretical and practical lessons of human anatomy for the undergraduate degree in nursing; 5) questionnaire after-school leveling expertise.

It should be added that, in this unit, there was a 30\% dropout, and the main reason the high school hours. As next steps, the executing team will review all questionnaires, prepare the lessons, program theoretical and practical research and plan follow-up activities in research projects in progress in the areas of nutrition and experimental surgery. Moreover, this result and the experience they had with these students will allow creation of future alternatives for a next entry project.

\section{DISCUSSION}

In Brazil, there are occasional reports of experiments similar to those described above. The Federal Fluminense University (New Friburg Unit, Rio de Janeiro), for example, two years ago had a local high school students insertion program through summer schools and social actions. The project was called Consciousness in Science and had the multidisciplinary format as well as with the institutional partnership with private universities, public universities and nongovernmental organiza- tion $^{14}$. Such actions can assist in the demands made by PNPG 2011-2020, which values the lines of research and graduate programs that have performances in the technological development and contribute to the development of Brazilian basic education. Consequently, we expect these improvements with actions in quality search and thus increase the production of qualified human resources and technological innovation.

However, the challenges are present, since the Brazilian basic education still suffers serious curricular deficiencies when compared to international curricula. In American schools, for example, students are provided with art history content, advanced calculus, geology and astronomy. In general, schools offer educators and challenging actions, the concept of preparation for higher education, with inclusion in its investigations and analysis, teamwork and problem solving with the formulation of an implementation plan. The San Francisco University High School, for example, has several insertion strategies, ranging from partnership for paid internship in the US Senate ("US Senate Youth Program Scholarship") to specific programs for medicine, as the "Pathways to medicine" which is based on experiential learning with practical exercises to cultivate the potential of students in medicine, thereby raising concerns for the areas of health, medicine and sciences ${ }^{15}$.

In addition, some American graduate programs, such as the Fox Chase Cancer Center (FCCC), receive pupils of primary and secondary education in its research centers. The main objective is to encourage participation in research and knowledge in science and medicine. In addition, students are inserted on the writing process, paper presentation at trade fairs and conferences, as well as the scientific publication ${ }^{16}$.

For many experts, initiatives like these, plus some educational policy issues already addressed above, contribute to the significant development of human, scientific and technological resources in the US and some European countries, such as England and Germany. Still, these cited countries have today leading universities and world development centers.

\section{CONCLUSION}

Scientific research, technological training and leadership in science are formed from a complex network of basic education, investment in research and entrepreneurship. However, despite the current challenges of Brazilian education, postgraduate courses, such as programs of Translational Surgery (UNIFESP) and Physiopathology and Surgical Sciences (UERJ), Medicine III - CAPES, follow the forefront with initiatives focused on scientific and technological development. Therefore, projects involving high and fundamental school students represent leader promoter model. 


\section{RESUMO}

Objetivo: Apresentar um projeto piloto de inserção do ensino médio em programas de pós-graduação (PPG) e discutir os mecanismos para a formação de líderes em ciência. Métodos: Realizou-se um estudo de revisão e apresentação de piloto. A busca bibliográfica ocorreu nos sites da CAPES, MEC, Scielo e biblioteca de livros virtuais, de janeiro/2014 a fevereiro/2015. O piloto ocorre nos PPG-Medicina III em Cirurgia Translacional/UNIFESP e Fisiopatologia e Ciências Cirúrgicas/UERJ. Os alunos de iniciação científica júnior (ICj) são oriundos de escola pública e desenvolvem atividades científicas: participação em reuniões científicas, graduação e inserção nos projetos de pesquisa. A avaliação ocorrerá ao final de um ano, com redações dos resultados, relatórios e participações em eventos científicos. Resultados: No Brasil, um dos principais desafios da educação é a alta média de anos de estudo. O PNPG (2011-2020) apresenta a inserção da educação básica em todos os PPG. Na Fisiopatologia e Ciências Cirúrgicas/UERJ há atualmente 11 alunos do ensino médio, que já acompanharam as reuniões científicas e preparam-se para a inserção em projetos de pesquisa. Houve 30\% de desistência, devido à alta carga horária escolar. Esse resultado e a experiência vivenciada permite criar alternativas futuras para aprimorar o projeto de inserção. Conclusão: A liderança em ciências é formada a partir de uma complexa relação entre educação básica e investimentos na pesquisa. Cursos de PPG-Medicina III seguem na vanguarda com iniciativas focadas no desenvolvimento científico e tecnológico. Assim, projetos envolvendo alunos da educação básica representam modelo e ambiente promotor de líderes.

Descritores: Pós-graduação. Educação. Ensino médio. Ensino fundamental. Liderança.

\section{REFERENCES}

1. GOLDENBERG, J. O repensar da educação no Brasil. Estudos Avançados, v.7, n.18, p. 65-137. 1993.

2. GONÇALVES, J. E. L. Os novos desafios da empresa no futuro. RAE - Rev Administração de Empresas, São Paulo, v.37, n. 3, p. 10-19. Jul/set, 1997.

3. ANDRÉ, M. E. D. A. A produção acadêmica sobre formação de professores: um estudo comparativo das dissertações e teses defendidas nos anos 1990 e 2000. Form. Doc. Belo Horizonte, v. 01, n. 01, p. 41-56, ago./dez., 2009.

4. PASCHOAL, J. D.; MACHADO, M. C. G. A história da educação infantil no Brasil: avanços, retrocessos e desafios dessa modalidade educacional. Rev HISTEDBR On-line, Campinas, n. 33, p. 78-95, mar. 2009.

5. OLIVEIRA, E. L.; SIQUEIRA, H. V. Avançar na pós-graduação e formar recursos humanos para o desenvolvimento do país. In: CAPES (Org.), Ministério da Educação. Coordenação de Aperfeiçoamento de Pessoal de Nível Superior. Plano Nacional de Pós-graduação - PNPG 2011-2020 / Coordenação de Pessoal de Nível Superior. Brasília, DF: CAPES, 2010; p. 29-33.

6. SCHWARTZMAN, J. Financiamento da pós-graduação no Brasil. In: CAPES (Org.), Ministério da Educação. Coordenação de Aperfeiçoamento de Pessoal de Nível Superior. Plano Nacional de Pós-graduação - PNPG 2011-2020 / Coordenação de Pessoal de Nível Superior. Brasília, DF: CAPES, 2010; p. 295-312.

7. ARANHA, M. L. de. História da educação. 2 ed. São Paulo: Moderna, 1996.

8. ZOTTI, S. A. Sociedade, Educação e Currículo no Brasil: dos jesuítas aos anos de 1980. Campinas: Autores Associados, 2004.
9. SILVA, E. M. P. Desenvolvimento tecnológico e inovação - nota sobre pós-graduação, desenvolvimento tecnológico e inovação. In: CAPES (Org.), Ministério da Educação. Coordenação de Aperfeiçoamento de Pessoal de Nível Superior. Plano Nacional de Pós-graduação - PNPG 2011-2020 / Coordenação de Pessoal de Nível Superior. Brasília, DF: CAPES, 2010; p. 191-216.

10. MARCONDES, D. A crise de paradigmas e o surgimento da modernidade. In: BRANDÃO, Z. (Org.). A crise dos paradigmas e a educação. 4 ed. São Paulo: Cortez, 1997, p.14-29.

11. GALVÃO, C.M. et al. A liderança do enfermeiro no século XXI: algumas considerações. Rev.Esc.Enf.USP, v.32, n.4, p. 302-6, dez. 1998

12. TREVIZAN, M.A.; MENDES, I.A.C.; FÁVERO, N.; MELO, M.R.A. da C. Liderança e comunicação no cenário da gestão em enfermagem. Rev. latino-am. enfermagem, Ribeirão Preto, v. 6, n. 5, p. 77-82, dezembro 1998

13. Educação brasileira: indicadores e desafios: documentos de consulta / Organizado pelo Fórum Nacional de Educação. -- Brasília: Ministério da Educação, Secretaria Executiva, Secretaria Executiva Adjunta, 2013. 95 p.

14. Consciência na ciência. Disponível em: < http://conscienciaciencia. wix.com/punf>. Acesso em: 13/02/2015.

15. San Francisco University High School. Disponível em: < http:// www. sfuhs.org/page.cfm?p=4885>. Acesso em: 13/02/2015.

16. Fox Chase Cancer Center. Disponível em: < http://www.fccc.edu/ research/facilities/index.html>. Acesso em: 10/02/2015.

Received on: 19/02/2015

Accepted for publication: 12/09/2015

Conflict of interest: none

Source of funding:

Address for correspondence:

Fernanda Amorim de Morais Nascimento

fernanda.amorim@gmail.com 